\title{
Implementation of Green Marketing Strategies and Green Purchase Behavior as Efforts to Strengthen the Competitiveness of MSMEs in Indonesia
}

\author{
Dinda Kayani Putri Bestari ${ }^{1}$, DJ Anderson Butarbutar ${ }^{2}$ \\ ${ }^{1,2}$ Faculty of Economy and Business, Universitas Widyatama, Bandung, Indonesia \\ dinda.kayani@widyatama.ac.id, Anderson.butarbutar@widyatama.ac.id
}

\begin{abstract}
The contribution of UMKM business actors is considered quite significant for the development of the economic structure, however, the UMKM sector players must still manage their strategies so that this contribution can continue to grow. To achieve sustainability and continue to make a positive contribution, MSMEs must have a business strategy and competitive power that are relevant to market conditions. The discussion about environmentally friendly products is increasingly being discussed. The high people's willingness to buy environmentally friendly products illustrates that more and more consumers are starting to become aware of environmental conservation and minimize environmental pollution due to the consumption of certain products. This is considered as an opportunity, companies try to respond positively and encourage companies to do innovative things by introducing new business strategies known as green marketing strategies. Researchers will try to see how green marketing strategies influence the trust of green customers, then how green marketing strategies and green customer trust affect green purchase intention and green purchase behavior in the MSME sector, especially in the type of handmade environmentally friendly Indonesian products. This study used the PLS (Partial Least Square) data analysis method using the SmartPLS version 3. The respondents in this study were 350 respondents spread across several regions of Indonesia. The technique of distributing questionnaires used the snowball sampling method. The research result states that green marketing strategies, green customers, and green purchase intention have a very big influence in shaping the behavior of purchasing environmentally friendly products for green consumers.
\end{abstract}

Keywords

Green marketing strategies, green customer trust; green purchase intention; green purchase behavior, SEM-PLS

\section{Introduction}

Environmental pollution and climate change which are considered to be extreme make people worry about the current environment. The community also feels concerned about the environment, which is increasingly polluted. The community thinks that environmental preservation is very important and people need to increase awareness of the environment. Concentration on environmental conservation is very important to avoid the impact of environmental problems (Risyamuka, 2014: 21).

Various efforts such as changing behavior and lifestyle are shown in order to contribute to reducing the impact of environmental problems by becoming a green consumer. Evidence for this change in purchasing behavior can be found in various surveys. For example, in July 1989, the MORI (Market and Opinion Research International) poll showed that the proportion of consumers choosing products based on "environmental performance" had increased from $19 \%$ to $42 \%$ in less than a year. 
The research results of H'Mida et al. (2008) in Waskito and Harsono (2012), revealed that four out of five consumers have expressed their opinion about the environment through purchasing behavior. Therefore, consumers who show a high level of environmental awareness make an increased purchasing decision for environmentally friendly products compared to products that are less concerned about this issue (Waskito and Harsono, 2012). Romdonny and Rosmadi (2019) stated that the better the product produced and useful, the more consumers will enjoy it, especially to meet their daily needs. The quality of products that are in great demand by consumers can be seen from several factors including packaging, price, quality, and benefits obtained by consumers.

The consumers are smarter and more conscientious in every purchase of a product, so that it makes the consumers ${ }^{\text {ee }}$ taste always fluctuative towards a product ${ }^{\text {ee }}$ demand caused by the environmental situation that keeps changing (Agustina and Karyono, 2019). Kotler 2012 in Kusumadewi (2019) suggested that Customer perceived value is the difference between the prospective customer's evaluation of all benefits and all costs of an offering and perceived alternatives. Total customer value is the perceived monetary value of the bundle of economic, functional and psychological benefit customer expect from a given market offering product. Total customer cost is the bundle of cost customer expect to incur in evaluating, obtaining, using and disposing of the given market offering.

According to the results of the Nielsen global survey in 2014 which examined corporate social responsibility actions, $55 \%$ of respondents said they were willing to pay more for products and services for companies that care about social and environmental issues (Global Neilsen, 2014).

The same thing was expressed through a survey conducted by MasterCard in 2014 which stated that as many as $58.8 \%$ of buyers in Asia Pacific bought environmentally friendly products, the poll results also concluded that Indonesian consumers $(78.7 \%)$ were most likely to consider a product whether it benefits both parties, is environmentally friendly or donates part of the profits to charity (Wibowo, 06 April 2015).

The discussion about environmentally friendly products is increasingly being discussed. The high people's willingness to buy environmentally friendly products illustrates that more and more consumers are starting to become aware of environmental conservation. This is seen as an opportunity and companies try to respond positively and encourage companies to do innovative things by introducing new business strategies which are known as green marketing strategies.

However, there may be consumers who do not or have not realized the importance of consuming environmentally friendly products. Ginsberg (2004: 79) states:

"While buying green may not appeal to everyone, there are substantial numbers of consumers who are potentially receptive to a green appeal. According to the Roper survey mentioned above, $58 \%$ of U.S. consumers try to save electricity at home, $46 \%$ recycle newspapers, $45 \%$ return bottles or cans and $23 \%$ buy products made from, or packaged in, recycled materials."

Based on the above statement, it can be interpreted that not everyone is willing to consume green products, but the percentage above needs to be considered. Companies need to fully understand their target consumers and need to identify whether greenness is a relevant sales attribute to consider and be considered in determining their marketing strategy. It can be seen from the current marketing process that the Company embodies environmentally friendly actions in their products and operations. They realize that by making these efforts they will not only help save the environment and society but will also help improve brand reputation and company performance. 
Based on the description of the above conditions, the researcher will try to see how green marketing strategies affect green customer trust, then how green marketing strategies and green customer trust affect green purchase intention in the MSME sector, especially in the original Indonesian handmade product category.

\section{Research Methods}

This research will be conducted with a quantitative research approach, based on the objective of this research is explanative research. Explanative research tries to find out the relationship between these things. This relationship can be in the form of a correlational relationship or mutual relationship, the contribution or contribution of one variable to other variables. Experiments are usually associated with hypothetical deductive approaches to research. The purpose of an experiment is to study the causal relationship between variables (Sekaran and Bougie, 2016: 99).

The variables in this study consisted of exogenous and endogenous variables. In this research, there are two exogenous variables, namely: Green marketing strategies and green customer trust. And there are two endogenous variables in this study, namely: green purchase intention and green purchase behavior.

The population in this study are consumers who have purchased environmentally friendly products known as green products, which are spread across several islands in Indonesia. The number of samples in this study some 350 respondents. The sampling technique uses snowball sampling. The data collection process uses a questionnaire that is distributed online and offline from March to November 2020.

The analysis phase using Partial Least Square (PLS) -SEM must go through at least a six-step process where each step will affect the next stage. The stages consist of: conceptualizing the model, determining the algorithm analysis method, determining the resampling method, drawing a path diagram, evaluating the model, and testing the hypothesis (Latan and Ghozali, 2012: 45). Furthermore, data processing techniques using the SEM method based on Partial Least Square (PLS) require 2 steps to assess the Fit Model of a research model (Ghozali, 2006). These stages include the PLS model specification stage, the measurement model testing phase, and the structural model testing phase. The software used is SmartPLS version 3.

\section{Results and Discussion}

\subsection{Testing the Measurement Model (Outer Model)}

The measurement model testing phase aims to test the validity and reliability of all indicators in the model. This test includes testing Convergent Validity, Discriminant Validity, and Composite Reliability. PLS analysis can be continued if all indicators in the PLS model have met the requirements of convergent validity, discriminant validity, and composite reliability. The results of the PLS model estimation in the measurement model testing phase can be seen in the following figure: 


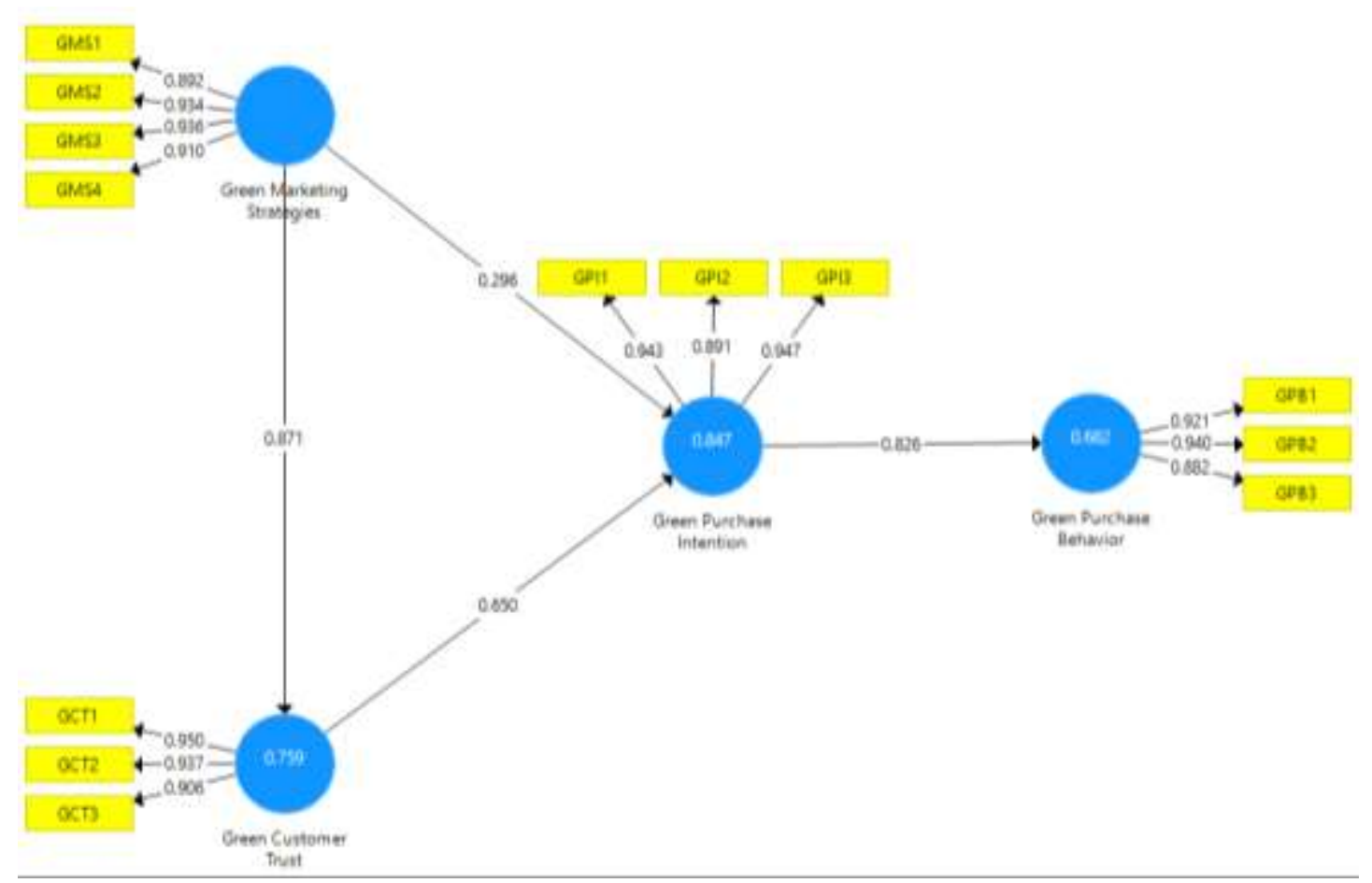

Figure 1. Measurement Model Estimation Results

Source: Results of Data Processing (2020)

\section{a. Convergent Validity}

A convergent validity test is done by looking at the loading factor value of each indicator against the construct. In this test, confirmatory research, the limit of loading factor used is 0.7, while for exploratory research the limit of loading factor used is 0.6. Because this study is confirmatory, the limit of loading factor used to test the convergent validity of each indicator is 0.7 . Then the loading factor value for each variable is obtained as follows:

Table 1. Convergent Validity Test Results

\begin{tabular}{|c|c|c|c|}
\hline Construct & Indicator & R. Count & Validity \\
\hline \multirow{4}{*}{$\begin{array}{c}\text { Green Marketing } \\
\text { Strategies }\end{array}$} & GMS1 & 0,892 & VALID \\
\cline { 2 - 4 } & GMS2 & 0,934 & VALID \\
\cline { 2 - 4 } & GMS3 & 0,936 & VALID \\
\cline { 2 - 4 } & GMS4 & 0,910 & VALID \\
\hline \multirow{3}{*}{$\begin{array}{c}\text { Green Customer } \\
\text { Trust }\end{array}$} & GCT1 & 0,950 & VALID \\
\cline { 2 - 4 } & GCT2 & 0,937 & VALID \\
\cline { 2 - 4 } & GCT3 & 0,906 & VALID \\
\hline \multirow{3}{*}{$\begin{array}{c}\text { Green Purchase } \\
\text { Inttention }\end{array}$} & GPI1 & 0,943 & VALID \\
\cline { 2 - 4 } & GPI2 & 0,891 & VALID \\
\cline { 2 - 4 } $\begin{array}{c}\text { Green Purchase } \\
\text { Behavior }\end{array}$ & GPI3 & 0,947 & VALID \\
\cline { 2 - 4 } & GPB1 & 0,921 & VALID \\
\cline { 2 - 4 } & GPB2 & 0,940 & VALID \\
\hline
\end{tabular}


Based on the table above, the value of the loading factor indicator for the construct is $>0.7$, which indicates that the indicators are valid.

\section{b. Discriminant Validity}

Discriminant validity is used to ensure that each concept of a latent variable is different from other variables. The model has good discriminant validity if each loading value of each indicator of a latent variable has the greatest loading value with other loading values against other latent variables. The results of discriminant validity testing were obtained as follows:

Table 2. Discriminant Validity Test Results

\begin{tabular}{|c|c|c|c|c|}
\hline & Green Customer Trust & Green Marketing Strategies & Green Purchase Beharior & Green Purchase intention \\
\hline Green Customes Trust & 0.931 & & & \\
\hline Green Marketing Strategies & 0.871 & 0.918 & & \\
\hline Green Purchase Behavior & 0.829 & 0.744 & 0.915 & \\
\hline Green Purchase Intertion & 0.909 & 0.863 & 0.826 & 0.927 \\
\hline
\end{tabular}

Source: Results of Data Processing (2020)

From the table above, it can be seen that all indicators have a loading factor value greater than the loading factor of the other constructs so that the model has met the required discriminant validity requirements.

\section{c. Composite Reliability dan Cronbach's Alpha}

Construct reliability can be assessed from the Cronbach's Alpha value, the Composite Reliability value, and the Average Variance Extracted (AVE) value of each construct. The construct is said to have a high reliability if the Cronbach's Alpha value exceeds 0.7, the composite reliability value exceeds 0.70 and the AVE value is above 0.50 .

Table 3. Construct Reliability Test Results

\begin{tabular}{|l|r|r|r|r|} 
& Cronbach's Alpha & rho_A & Composite Reliability & Average Variance Extracted (AVE) \\
\hline Green Custom... & 0.923 & 0.925 & 0.951 & 0.867 \\
\hline Green Marketin... & 0.938 & 0.940 & 0.956 & 0.843 \\
\hline Green Purchas... & 0.903 & 0.915 & 0.939 & 0.837 \\
\hline Green Purchas... & 0.918 & 0.920 & 0.948 & 0.860 \\
\hline
\end{tabular}

Source: Results of Data Processing (2020)

Based on the table above, it can be seen that the Cronbach's alpha value of all constructs is $>0.7$, the composite reliability value is $>0.7$ and the AVE value of all constructs is $>0.5$ which means that all constructs have met the reliability.

\subsection{Inner Model}

\section{a. R Square}

The PLS Structural Model can be assessed by looking at the R Square value of each endogenous variable as the predictive strength of the structural model. The $\mathrm{R}$ Square interpretation is the same as the $\mathrm{R}$ Square interpretation in ordinary regression analysis. $\mathrm{R}$ Square values of $0.75 ; 0.50$ and 0.25 can be concluded that the model is strong, moderate and weak (Ghozali; 2014). The following is the R Square value of the research variables: 
Table 4. Value of R Square

\begin{tabular}{|l|r|r|} 
& R Square & R Square Adjusted \\
Green Customer Trust & 0.759 & 0.756 \\
\hline Green Purchase Behavior & 0.682 & 0.679 \\
Green Purchase Intention & 0.847 & 0.844 \\
\hline
\end{tabular}

Source: Results of Data Processing (2020)

The R-Square value above illustrates the amount of the contribution of each variable.

\section{b. Effect Size (f Square / f2)}

In PLS analysis, the value of $\mathrm{f}$ square (f2) shows the influence of each predictor variable on the endogenous variables. According to Cohen (1988) in (Ghozali, 2014), the f square value obtained can then be categorized into the category of small effect ( $\mathrm{f} 2=0.02$ ), medium effect ( $\mathrm{f} 2=0.15$ ) and large effect $(\mathrm{f} 2=0.35)$. ). The following is the $\mathrm{f} 2$ value of each exogenous variable for endogenous variables:

Table 5. Value of F Square

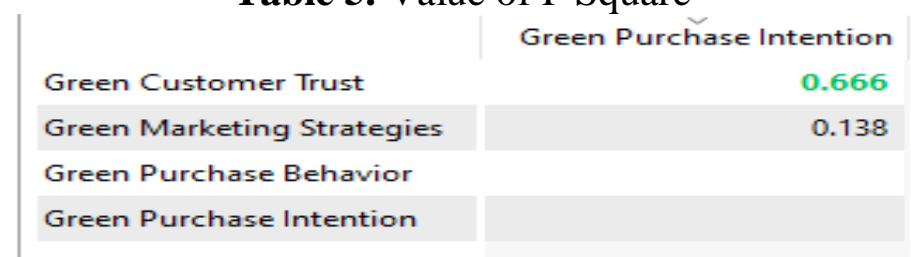

Source: Results of Data Processing (2020)

The results of the calculation off square in table 6 are as follows:

The $f$ square value of the Green Customer Trust variable on Green purchase intention is 0.666 , while the f square value for the Green Marketing Strategy variable on Green Purchase Intention is 0.138. This shows that Green Marketing Strategies has a small effect and Green Customer Trust has a large effect on Green Purchase Intention. So the contribution given by the Green Customer Trust variable to Green Purchase Intention is higher than the contribution of the Green Marketing Strategies variable to Green Purchase Intention.

\section{- Q2 Predective relevance}

In the PLS analysis, $\mathrm{Q}^{2}$ shows the predictive power of the model. The $\mathrm{Q}^{2}$ value of the model is 0.02 , indicating that the model has a weak predictive relevance, the $\mathrm{Q}^{2}$ value of the model is 0.15 , which indicates that the model has a moderate predictive relevance and the $\mathrm{Q}^{2}$ value of the model is 0.35 indicating that the model has a strong predictive relevance. The formula used to calculate $\mathrm{Q}^{2}$ is as follows:

$\mathrm{Q}^{2}$ formula:

With:

$$
\mathrm{Q}^{2}=1-\left(1-\mathrm{R}^{2}{ }_{1}\right)\left(1-\mathrm{R}^{2}{ }_{2}\right) \ldots \ldots\left(\mathrm{R}_{\mathrm{k}}{ }\right)
$$

$\mathrm{k}=$ number of endogenous variables

$\mathrm{R}^{2}{ }_{1}=1$ st endogenous variables

$\mathrm{R}^{2}{ }_{2}=2$ nd endogenous variables

$\mathrm{R}^{2}{ }_{\mathrm{k}}=\mathrm{k}$ endogenous variables

$Q^{2}=1-(1-0,759)(1-0,682)(1-0,847)$

$\mathrm{Q}^{2}=\mathbf{0 , 9 8 8}$

The result of the above calculation is a value $Q^{2}$ a model of $0,988>0,35$ which shows that the model has a strong predictive relevance. 


\section{- Goodness of fit (Gof) test}

The goodness of fit test of the PLS model can be seen from the calculated value with the following formula:

$$
\begin{aligned}
& \text { GoF }=\sqrt{\frac{A V E \times R^{2}}{}} \\
& \text { GoF }=0,8052
\end{aligned}
$$

Value:

$\underline{\text { AVE }}=0,851$

$\underline{R^{2}}=0,762$

According to Tenenhaus, et.al. (2004) the provisions are; GoF is said to be small if the value is $\geq 0.1$, GoF is said to be medium if the value is $\geq 0.25$, and GoF is said to be large if the value is $\geq 0.38$.

The results of the calculation show that this research model obtained a GoF value of 0,8052 , it can be said that the model has a large GoF and is declared to have met the goodness of fit criteria, so it is suitable to be used to test the research hypothesis.

\section{- Significance Test}

The results of the model fit test, the calculation of the value of $\mathrm{R}$ Square, $\mathrm{f}$ square, and Q square show that the PLS model that has been built is feasible to be used to test the hypothesis in research. The hypothesis used in this test is as follows:

H1: The Green Marketing Strategies variable has a significant effect on the Green Customer Trust variable.

H2: The Green Marketing Strategies variable has a significant effect on the Green Purchase Intention variable.

H3: The Green Customer Trust variable has a significant effect on the Green Purchase Intention variable.

H4: The Green Purchase Intention variable has a significant effect on the Green Purchase Behavior variable.

With a significant level of 0.05 , Ho will be rejected if the P-value $<0.05$ and $t$ count $>1.96$, whereas if the $\mathrm{p}$ value $>0.05$ and $\mathrm{t}$ count $<1.96$ then Ho is not rejected. From the results of the significance test, it can also be seen in the direction of the relationship between the influence of exogenous and endogenous variables. The direction of the relationship can be seen from the original sample value of each effect relationship. If the direction of the relationship of influence is positive, then the effect of exogenous variables on endogenous variables is positive/unidirectional, whereas if the original sample is negative, the direction of the relationship between exogenous variables and endogenous variables is opposite.

The results of the model estimation as a reference for testing the hypothesis in this study can be seen in the following figure: 


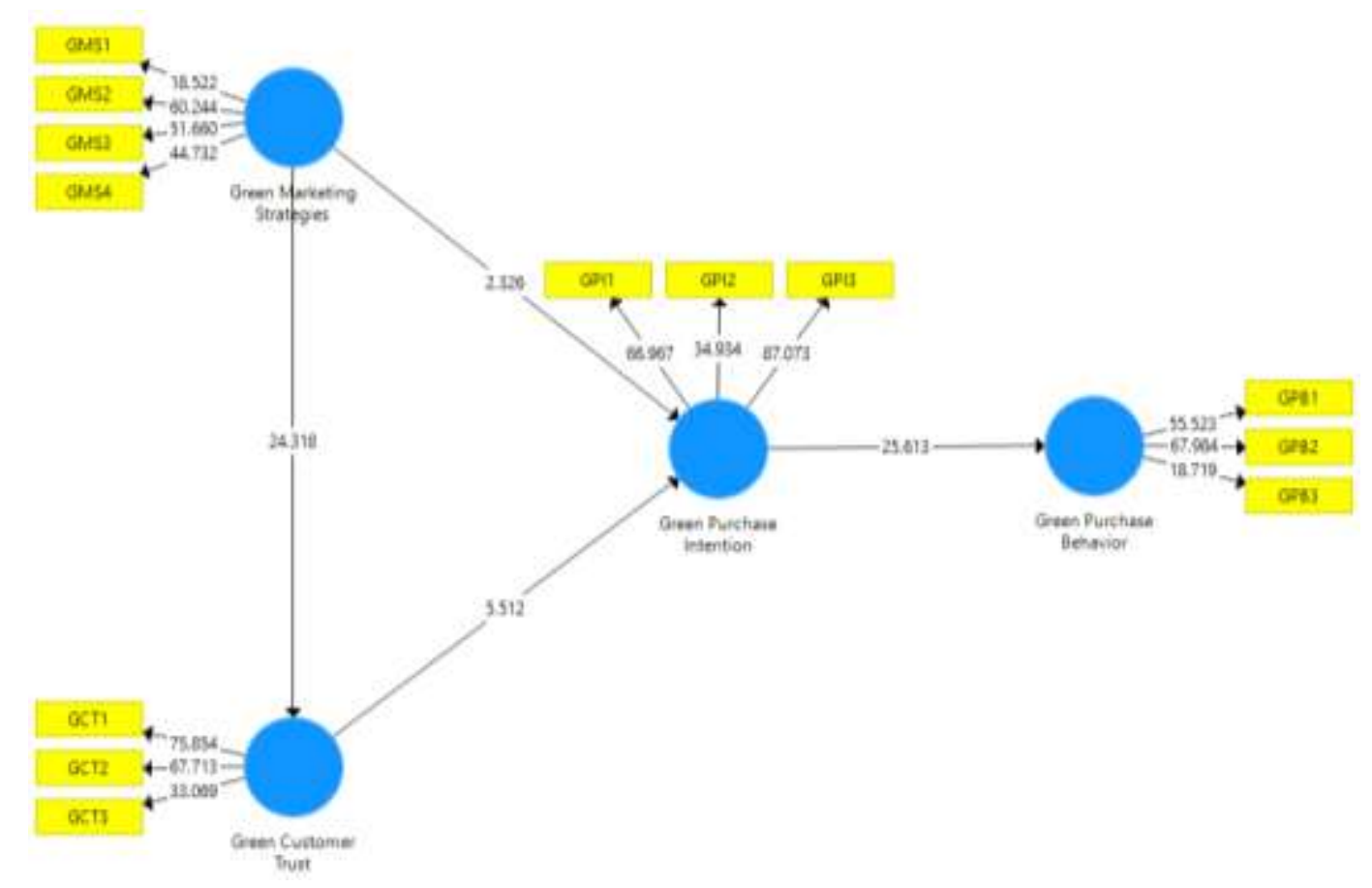

Figure 2. Bootstrapping Test Results

Source: Results of Data Processing (2020)

The complete test results can be seen in the following table:

Table 6. Model Estimation Results

\begin{tabular}{|c|c|c|c|c|c|}
\hline \\
\hline & Original Sample (0) & Sample Mean (M) & Standard Deviation (STDEV) & TStatistics (|O/STDEV|) & P Values \\
\hline Green Customer Trust -> Green Purchase Intention & 0.650 & 0.644 & 0.118 & 5.512 & 0.000 \\
\hline Green Marketing Strategies -> Green Customer Trust & 0.871 & 0.873 & 0.036 & 24.318 & 0.000 \\
\hline Green Marketing Strategies -> Green Purchase Intention & 0.296 & 0.305 & 0.127 & 2.326 & 0.020 \\
\hline Green Purchase Intention $->$ Green Purchase Behavior & 0.826 & 0.827 & 0.032 & 25.613 & 0.000 \\
\hline
\end{tabular}

Source: Results of Data Processing (2020)

Based on table 5.16 above, the following results are obtained:

1. The p-value of the influence of the green marketing strategies variable on green customer trust is 0.000 with a $\mathrm{T}$ statistic of 24.318 and the original sample is positive. Because the significant value obtained is $<0.05$ and $\mathrm{T}$ statistic $>1.96$, it is concluded that the green marketing strategies variable has a significant effect on green customer trust. This means that the better the implementation of green marketing strategies, the higher the green customer trust, and vice versa.

2. The p-value of the influence of the green marketing strategies variable on green purchase intention is 0.020 with a $\mathrm{T}$ statistic of 2.326 and the original sample is positive. Because the significant value obtained is $<0.05$ and $\mathrm{T}$ statistic $>1.96$, it is concluded that the green marketing strategies variable has a significant effect on green purchase intention. This means that the better the implementation of green marketing strategies, the higher the green purchase intention, and vice versa.

3. The p-value of the influence of the green customer trust variable on green purchase intention is 0,000 with a $\mathrm{T}$ statistic of 5.512 and the original sample is positive. Because 
the significant value obtained is $<0.05$ and the $T$ statistic $>1.96$, it is concluded that the green customer trust variable has a significant effect on green purchase intention. This means that the higher the green customer trust, the higher the green purchase intention, and vice versa.

4. The p-value of the effect of the green purchase intention variable on green purchase behavior is 0,000 with a $\mathrm{T}$ statistic of 25.613 and the original sample is positive. Therefore, the significant value obtained is $<0.05$, and the $T$ statistic $>1.96$, it is concluded that the green purchase intention variable has a significant effect on green purchase behavior. This means that the greater the green purchase intention, the greater the green purchase behavior, and vice versa.

Besides, there is also the amount of influence that each indicator has on each variable. The results of the significance test for each indicator are as follows:

Table 7. Model Estimation Results (per Indicator)

\begin{tabular}{|c|c|c|c|c|c|}
\hline \\
\hline & Original Sample $(0)$ & Sample Mean (M) & Standard Deviation (STDEV) & TStatistics (|O/STDEV|) & P Values \\
\hline GCT1 $<-$ Green Customer Trust & 0.950 & 0.950 & 0.013 & 75.854 & 0.000 \\
\hline GCT2 $<-$ Green Customer Trust & 0.937 & 0.937 & 0.014 & 67.713 & 0.000 \\
\hline GCT3 $<-$ Green Customer Trust & 0.906 & 0.903 & 0.027 & 33.069 & 0.000 \\
\hline GMS1 <- Green Marketing Strategies & 0.892 & 0.889 & 0.048 & 18.522 & 0.000 \\
\hline GMS2 <- Green Marketing Strategies & 0.934 & 0.935 & 0.016 & 60.244 & 0.000 \\
\hline GMS3 <- Green Marketing Strategies & 0.936 & 0.934 & 0.018 & 51.660 & 0.000 \\
\hline GMS4 <- Green Marketing Strategies & 0.910 & 0.910 & 0.020 & 44.732 & 0.000 \\
\hline GPB1 <- Green Purchase Behavior & 0.921 & 0.920 & 0.017 & 55.523 & 0.000 \\
\hline GPB2 <- Green Purchase Behavior & 0.940 & 0.939 & 0.014 & 67.984 & 0.000 \\
\hline GPB3 <- Green Purchase Behavior & 0.882 & 0.879 & 0.047 & 18.719 & 0.000 \\
\hline
\end{tabular}

\section{- Hypothesis Testing}

The results of the PLS analysis are then used to test the research hypothesis, here is a summary of the results of testing the research hypothesis based on the results of the PLS analysis.

Table 8. Hypothesis Test

\begin{tabular}{|c|l|c|c|c|}
\hline No & \multicolumn{1}{|c|}{ Hypothesis } & T Statistics & P Value & Conclusion \\
\hline 1 & $\begin{array}{l}\text { Green Marketing } \\
\text { Strategies has a significant } \\
\text { influence on green } \\
\text { customer trust. }\end{array}$ & 24,318 & 0,000 & $\begin{array}{c}\text { Hypothesis } \\
\text { accepted }\end{array}$ \\
\hline $\begin{array}{l}\text { Green Marketing } \\
\text { Strategies has a significant } \\
\text { influence on green } \\
\text { purchase intention }\end{array}$ & $\begin{array}{l}\text { Green Customer Trust has } \\
\text { a significant influence on } \\
\text { Green Purchase Intention. }\end{array}$ & $\begin{array}{l}\text { Green Purchase Intention } \\
\text { has a significant influence } \\
\text { on Green Purchase } \\
\text { Behavior. }\end{array}$ & 25,326 & 0,020 \\
\hline
\end{tabular}

Source: Results of Data Processing (2020) 
Based on the results of data processing with the Partial Least Square Analysis technique using the Smart PLS 3.0 software as a tool, it is found as follows:

a. Green Marketing strategies have a significant effect on green customer trust.

The $\mathrm{p}$-value of the influence of the green marketing strategies variable on green customer trust is 0.000 with a $\mathrm{T}$ statistic of 24.318 and the original sample is positive. Because the significant value obtained is $<0.05$ and $T$ statistic $>1.96$, it is concluded that the green marketing strategies variable has a significant effect on green customer trust. This means that the better the implementation of green marketing strategies, the higher the green customer trust. Conversely, if the worse the implementation of green marketing strategies, the lower the green customer trust. The results of this study prove that the hypothesis presented by the author can be proven, namely that there is a positive and significant influence between green marketing strategies in determining green customer trust. A marketing strategy that supports the environment and considers the impact on the environment is one of the things that must be prioritized by a company because thus green consumer confidence will be higher.

b. Green Marketing Strategies has a significant effect on green purchase intention

The p-value of the influence of the green marketing strategies variable on green purchase intention is 0.020 with a $\mathrm{T}$ statistic of 2.326 and the original sample is positive. Because the significant value obtained is $<0.05$ and $T$ statistic $>1.96$, it is concluded that the green marketing strategies variable has a significant effect on green purchase intention. This means that the better the implementation of green marketing strategies, the higher the green purchase intention. Conversely, if the worse the implementation of green marketing strategies, the lower the green purchase intention. The results of this study prove that the hypothesis presented by the author can be proven, namely that there is a positive and significant influence between green marketing strategies in determining green purchase intention. Implementing a marketing strategy that supports the environment and considers the impact on the environment can increase the intention to buy environmentally friendly products and carry out activities that support the ecological movement.

c. Green Customer Trust has a significant effect on Green Purchase Intention.

The p-value of the influence of the green customer trust variable on green purchase intention is 0.000 with a $\mathrm{T}$ statistic of 5.512 and the original sample is positive. Because the significant value obtained is $<0.05$ and the T statistic $>1.96$, it is concluded that the green customer trust variable has a significant effect on green purchase intention. This means that the higher the green customer trust, the higher the green purchase intention. Conversely, if the lower the green customer trust, the lower the green purchase intention. The results of this study prove that the hypothesis presented by the author can be proven, namely that there is a positive and significant influence between green customer trusts in determining green purchase intention. It can be seen that green consumer confidence refers to individual beliefs about the perceived quality of environmentally friendly products, the perceived risk when buying and consuming environmentally friendly products, and customer satisfaction in using environmentally friendly products.

d. Green Purchase Intention has a significant effect on Green Purchase Behavior

The p-value of the effect of the green purchase intention variable on green purchase behavior is 0,000 with a $\mathrm{T}$ statistic of 25.613 and the original sample is positive. Therefore, the significant value obtained is $\langle 0.05$, and the T statistic $\rangle 1.96$, it is concluded that the green purchase intention variable has a significant effect on green purchase behavior. This means that the greater the green purchase intention, the greater 
the green purchase behavior. Conversely, if the lower the green purchase intention, the lower the green purchase behavior that is formed. The results of this study prove that the hypothesis presented by the author can be proven, namely that there is a positive and significant influence between green purchase intention in determining green purchase behavior. Based on this, it can be seen that a person's intention to buy environmentally friendly products and carry out activities that support the ecological movement characterizes a green behavior, where the act of consuming the product is carried out, always consider the concept of sustainability, consumption that provides benefits to the environment, and can address/respond to problems. environment.

\section{Conclusion}

Based on this research, it can be concluded that several things need to be the attention of business actors (MSMEs) in Indonesia in implementing strategic novelty. The discussion about environmentally friendly products becomes an interesting topic of conversation. The high people's willingness to buy environmentally friendly products illustrates that more and more consumers are starting to become aware of the importance of protecting the environment. MSMEs players in Indonesia should respond to this as a business opportunity that provides opportunities for companies to create superior value in the eyes of consumers. This is done to increase the competitiveness of these MSME business actors so that they can continue to develop and make continuous innovation.

\section{References}

Agustina, K., and Karyono, O. (2019). Developing A Superior Business Strategy Through Industrial Environment And Resources In Manufacturing Smes In West Java Province. Budapest International Research and Critics Institute-Journal (BIRCIJournal). P. 433-442.

Chen, Y. S., and Chang, C. H. (2012). The Roles of Green Perceived Value, Green Perceived Risk, and Green Trust Enhance Green Purchase Intention. Management Decision, 502-520.

Erlangga, H. (2020). The Challenges of Organizational Communication in the Digital Era. Solid State Technology, 63(4), 1240-1246.

Erlangga, H., Sifatu, . W. O., Wibisono, . D., Siagian, . A. O., Salam, . R., Mas'adi, . M., Gunartin, ., Oktarini, . R., Manik, . C. D., Nani, ., Nurhadi, . A., Sunarsi, . D., Purwanto, . A. \& Kusjono, . G. (2020) Pharmaceutical Business Competition in Indonesia: A Review. Systematic Reviews in Pharmacy, 11 (10), 617-623. doi:10.31838/srp.2020.10.92

Ghozali, Imam. (2014). Structural Equation Modeling, Alternative Methods. Partial Least Square (PLS). 4th Edition Semarang: University Publishing Agency.

Jasmani, J., Sutiman, S., \& Sunarsi, D. (2020). Analysis of the Effect of Prices, Promotions and Products on Purchase Interest Impacts on Consumer Satisfaction of VIVO Brand Mobile Phones in South Tangerang Region. Jurnal Ad'ministrare, 7(1), 73-82.

Kotler, Keller. (2016). Marketing Management. 15e, Boston, Pearson Education.

Kusumadewi, R. (2019). The Role of Marketing and Individual Environment Association in Elevating the Customer Value. Budapest International Research and Critics Institute-Journal (BIRCI-Journal). P. 451-460. 
Latan, Hengky., Ghozali. (2012). Partial Least Square Concepts, Techniques, and Applications: Using the SmartPLS 2.0 M3 Program. Diponegoro University Publishing Agency: Semarang.

Mulyono, Kemal Budi. (2018). The Role of Antecedent Green Purchase Intention on Green Purchase Behavior. Journal of Economic Education Scientific Vol. 3, No.1, 2018.ISSN: 2615-6784 (online).

Romdonny, J., and Rosmadi, M.L.N. (2019). Factors Affecting Customer Loyalty in Products. Budapest International Research and Critics Institute-Journal (BIRCIJournal). P. 337-343.

Sunarsi, D. (2020). The Influence of Supply Chain Strategy on Employee Performance on Small and Medium Business in Beringharjo Market, Yogyakarta- Indonesia. International Journal of Supply Chain Management. Vol. 9, No. 5

Wang, Z. \& Yu, H. (2007). A Empirical Study of Purchase Behavior on Green Food. Journal of Anhui Agriculture Science, 35 (10), 56- 58.

$\mathrm{Wu}$ and Chen. (2014). The Impact of Green Marketing and Perceived Innovation on Purchase Intention for Green Products. International Journal of Marketing Studies. 6 (5): 81-108. 